\title{
Future educators' perceptions on technology and livelihood education status and development of work skills
}

\author{
Rovelina B. Jacolbia ${ }^{1, *}$
}

Polytechnic University of the Philippines, Manila, Philippines

\section{Keywords:}

Status

Technology

Livelihood education

Work skills

Received: 7 March 2016

Accepted: 10 March 2016

Published: 26 April 2016

\begin{abstract}
This study aimed to determine the Technology and Livelihood Education Program status and students' work skills development. The study made use of a descriptive type of research. It involved 125 randomly selected second-year and third-year Bachelor in Business Teacher Education students of the Polytechnic University of the Philippines using the survey questionnaire as the major instrument in gathering the data. The mean average was used to describe the status of the TLE program in terms of curriculum content, instructional methods, faculty competence, adequacy of facilities, and the development of work skills and work attitudes of students. The Pearson Product Moment Correlation was used to determine the relationship of the TLE program with the development of students' work skills. The study revealed that the Status of Technology and Livelihood Education Program positively affects work skills development.
\end{abstract}

(c) 2016 The Author(s). Published by TAF Publishing.

\section{INTRODUCTION}

Among the learning areas, the Technology and Livelihood Education subject is the most experiential, interactive, interdisciplinary and value-laden (cultural, aesthetic, vocational, political-economic and moral values). It is in this learning area that provides the Filipino learners the quality time to demonstrate practical knowledge and life's skills that have been gained, especially the skills of vocational efficiency and empathy (De Alca, 2008).

Technology and livelihood education is vital to becoming a productive member of the modern workforce. Choosing a career path and then learning the technology related to that field or industry can be an excellent way to improve the chances of succeeding in a career endeavor. Technology education is widely available but it is not always free. Typically, students will attend vocational

\footnotetext{
* Corresponding author: Rovelina B. Jacolbia

E-mail: rovelinajacolbia@yahoo.com
} 
schools, technical colleges and universities to learn technology, including computer programming.

Technology and Livelihood Education intends to develop knowledge, skills, values and attitudes that will prepare the students for entry into the world of work. This will enable the students to gain understanding and acquire competencies in various activities as they relate to Home Economics, Agriculture Arts, Industrial Arts and Entrepreneurship (Calmorin, 1994).

The study of Technology and Livelihood Education needs redirection to suit the conditions in today's society and to promote advancement in knowledge and respond to the needs of individuals, families and the community (Sizoo, 2005).

In this light, the acquisition of knowledge and skills as well as values and attitudes necessary to help the learners enter the world of work should be given emphasis.

Schools have the responsibility to uplift every student's academic and lifelong learning. In due time, these students are expected to contribute significantly to the development of dynamic and self-sustaining economy, the pursuit of a better quality of life and the attainment of global competitiveness.

With the present economic conditions, the kind of education that the students should acquire must be within the mainstream of workforce which can provide benefits to improve their lives. The Technology and Livelihood Education is one of the subjects in the BBTE curriculum, which offers opportunity to prepare students in the world of work which trains the students to apply basic concepts and imbibe values related to practical work experiences.

First, the study aimed to determine the Technology and Livelihood Education program in terms of curriculum content, instructional methods, faculty competence, and adequacy of facilities.

Second, the study also looked at the development of the students' work skills.

Finally, the study wants to look at the relationship between the Technology and Livelihood Education status and development of students' work skills.

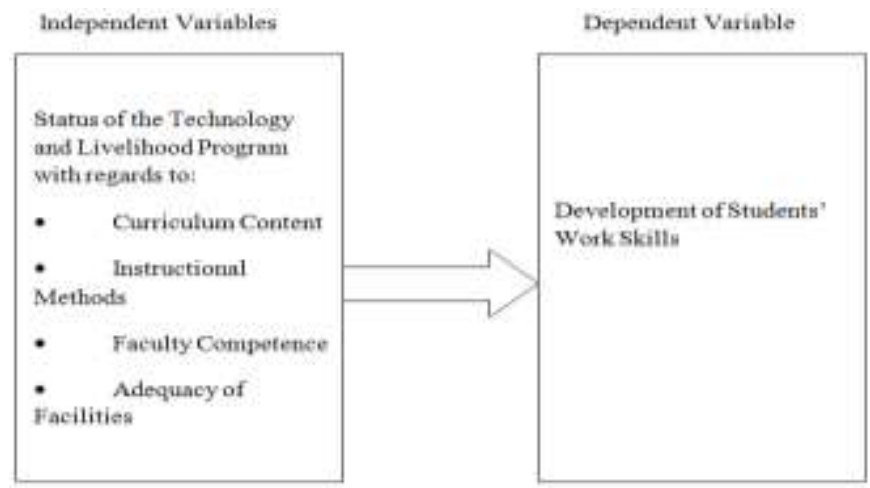

FIGURE 1. Research model

The Technology and Livelihood program status in terms of curriculum content, instructional methods, faculty competence, and adequacy of facilities are the independent variables. The dependent variable is the development of students' work skills. 


\section{METHODOLOGY}

The respondents of the study are 125 randomly selected second year and third year Bachelor in Business Teacher Education students of the Polytechnic University of the Philippines who are officially enrolled in the school year 20132014. The survey questionnaire is the major instrument used in gathering the data. Simple random sampling was used in choosing the samples. Bachelor in Business Teacher Education students are future educators of Technology and Livelihood Education program.

The study aimed to discover the status of the TLE program as: curriculum content, instructional methods, faculty competence and adequacy of facilities; how the status relates to the level of students' development in terms of work skills was the main focus of this study.

\section{RESULTS AND DISCUSSION}

TABLE 1. Weighted mean of the curriculum content

\section{Curriculum Content}

WM VI

1. Develops understanding of the different work activities and their significant contributions to personal, family and economic development.

2. Acquires working knowledge on the utilization and consumption of materials, products and services.

3. Develops greater proficiency in the use of tools, machines, equipment and material resources in the environment.

\begin{tabular}{lcc}
\hline 4. Appreciates the economic and social opportunities offered by the different occupations. & 3.91 & VG \\
\hline $\begin{array}{l}\text { 5. Manifests desirable attitudes and work values, essential for effective, personal, family and community } \\
\text { living. }\end{array}$ & 4.04 VG \\
\hline 6. Is dynamic in its approaches and activities. & 3.98 & VG \\
\hline 7. Meets the needs and expectations of the students and the community. & 3.94 & VG \\
\hline 8. Prepares technologically literate students for success in an ever-changing work place. & 3.99 & VG \\
\hline 9. Promotes the holistic growth of the learners and enables them to acquire the core competencies. & 4.04 & VG \\
\hline 10. Is relevant and responsive to our rapidly changing world. & 4.03 & VG \\
\hline \multicolumn{1}{|c|}{ Overall Weighted Mean } & $\mathbf{4 . 0 2}$ & VG \\
\hline \hline
\end{tabular}

As shown in Table 1, the respondents perceived the curriculum content as very good with a mean rating of 4.02. The first item got the highest weighted mean which indicates that they develop understanding of the different work activities and their significant contributions to personal, family and economic development. The fourth item got the lowest weighted mean which states that students appreciate the economic and social opportunities offered in the different possible available occupations. The curriculum should envelope a myriad of practical subjects as well as subjects in the arts and mechanics. Students should have the chance to experience the wide variety of opportunities in life outside of school. Young children should have a better chance to find out what their interests are with a diverse curriculum and older students should be able to pursue their interests with chosen electives (Holt, 2007).

As revealed in Table 2, respondents perceived the instructional methods as very good with a mean rating of 3.94. The first item got the highest weighted mean which specifies that through the instructional methods, the objectives of the lesson are explained clearly and developed the lessons logically. 
TABLE 2. Weighted mean of instructional methods

\begin{tabular}{lcc}
\hline \hline \multicolumn{1}{c}{ Instructional Methods } & WM & VI \\
\hline 1. Explain clearly the objectives of the lesson and develop the lesson logically. & 4.09 & VG \\
\hline 2. Utilize appropriate instructional aids. & 3.83 & VG \\
\hline 3. Keep majority of the students involved in the learning task most of the time. & 4.01 & VG \\
\hline 4. Require textbooks and instructional materials available to all students. & 3.77 & VG \\
\hline 5. Trust students by delegating and giving them freedom to perform in their own unique way. & 3.96 & VG \\
\hline 6. Employ current, experimental and creative approaches in teaching. & 3.90 & VG \\
\hline 7. Reflect a balanced coverage of subject contents through laboratory activities. & 3.98 & VG \\
\hline 8. Adapt method of teaching to the needs and capabilities of the students. & 3.86 & VG \\
\hline 9. Use appropriate tools for assessing the effectiveness of teaching. & 4.01 & VG \\
\hline 10. Use appropriate tools for assessing the progress of the students. & 3.98 & VG \\
\hline \hline
\end{tabular}

The fourth item got the lowest weighted mean which states that the instructional methods require textbooks and instructional materials which are readily available to them. The best teachers are not always, not even usually, those teachers with the most sophisticated content knowledge. The best teachers do know their material, but they also know a lot about the process. They have at their disposal a repertoire of instructional methods, strategies, and approaches-a repertoire they continually cultivate, just as they develop content knowledge. They never underestimate the power of the process to determine student learning outcomes (Weimer, 2008).

TABLE 3. Weighted mean of faculty competence

\begin{tabular}{lcc}
\hline \hline \multicolumn{1}{c}{ Faculty Competence } & WM & VI \\
\hline 1. Shows evidence of mastery of the subject matter taught. & 4.21 & VS \\
\hline 2. Institutes and adapts techniques appropriately, effectively and systematically. & 4.15 & VS \\
\hline 3. Selects, prepares and utilizes instructional aids and devices effectively and appropriately. & 4.08 & VS \\
\hline 4. Undertakes varied lessons, opportunities, situation and activities within the level of the learners. & 3.95 & VS \\
\hline 5. Expresses ideas in a well-organized manner and stimulates a two-way flow of communication. & 3.91 & VS \\
\hline 6. Makes full, productive use of the allotted time. & 3.99 & VS \\
\hline 7. Induces and sustains student's interest in the subject matter. & 3.99 & VS \\
\hline 8. Supervises all students in the performance of tasks given to them. & 4.02 & VS \\
\hline 9. Maintains proper classroom atmosphere. & VS & 4.03 \\
\hline 10. Relates the lesson with other subject areas. & Overall Weighted Mean & VS \\
\hline \hline
\end{tabular}

In Table 3, the respondents said that they perceived the faculty competence as very satisfactory with 4.04 mean rating. The first item got the highest weighted mean which indicates that the teacher shows evidence of mastery of the subject matter taught. The fifth item got the lowest mean rating which states that the teachers express ideas in a well-organized manner and stimulate a two-way flow of communication. A teacher who maintains an orderly classroom is effective in classroom management. From this stand point, teachers are expected to show effective managerial skill that can be demonstrated in his/her utilization of classroom resources such as teaching aids, necessary devices and equipment learning (Aquino, 2000). 
TABLE 4. Weighted mean of adequacy of facilities

\begin{tabular}{|c|c|c|}
\hline Adequacy of Facilities & WM & VI \\
\hline 1. Laboratory rooms are made available for the different TLE courses & 3.77 & VA \\
\hline 2. Laboratory rooms' size is enough for the number of students per class. & 3.64 & VA \\
\hline 3. The laboratories are strategically located. & 3.64 & VA \\
\hline $\begin{array}{l}\text { 4. The laboratories are equipped with demonstration areas, appropriate furniture, fixtures and } \\
\text { equipment. }\end{array}$ & 3.54 & VA \\
\hline 5. The laboratories are well lighted and well ventilated. & 3.66 & VA \\
\hline 6. The laboratories enable the students to do varied learning activities. & 3.63 & VA \\
\hline 7. The laboratories are provided with fire extinguishers and other safety devices. & 3.59 & VA \\
\hline $\begin{array}{l}\text { 8. Procurement of equipment, supplies and software supplies is made periodically to upgrade and } \\
\text { update existing units and holdings. }\end{array}$ & 3.68 & VA \\
\hline 9. Books, journals and magazines for lectures are made available to students. & 3.65 & VA \\
\hline 10. There are adequate instructional materials to facilitate learning. & 3.75 & VA \\
\hline Overall Weighted Mean & 3.66 & VA \\
\hline
\end{tabular}

As presented in Table 4, the respondents perceived the facilities as very adequate with a weighted mean of 3.66. The first item got the highest weighted mean which indicates that laboratory rooms are made available to different TLE courses. The fourth item got the lowest mean rating which states that the laboratories are equipped with demonstration areas, appropriate furniture, fixtures and equipment. Equally important for TLE instructions is the availability of adequate and up-to-date material resources in every school. Functional tools and equipment must be readily available for use of students. School facilities should be responsive to the changing programs of educational delivery. School facilities should provide an environment that is safe, secure, comfortable, accessible, well-ventilated, well-illuminated, aesthetically pleasing, and should be an integral component of the conditions of learning (Lackney, et al. 2008).

TABLE 5. Weighted mean of students' work skills

\begin{tabular}{lcc}
\hline \hline \multicolumn{1}{c}{ Work Skills of the Students } & WM & VI \\
\hline 1. Develop effective and efficient ways of accomplishing a certain task. & 4.22 & VS \\
\hline 2. Utilize time productively. & 4.08 & VS \\
\hline 3. Perform well in doing basic skills. & 4.10 & VS \\
\hline 4. Observe proper care and maintenance of tools and equipment. & 3.96 & VS \\
\hline 5. Construct worthwhile projects. & 4.10 & VS \\
\hline 6. Develop skills needed by professionals. & 4.14 & VS \\
\hline 7. Apply accurately the theories learned. & 4.14 & VS \\
\hline 8. Use and operate sophisticated tools, machines, instruments and equipment. & 4.02 & VS \\
\hline $\begin{array}{l}\text { 9. Acquire knowledge and information essential for making an intelligent choice of an occupation or } \\
\text { career. }\end{array}$ & VS \\
\hline 10. Maximize one's potentials for self-fulfillment. & Overall Weighted Mean \\
\hline \hline
\end{tabular}

As shown in Table 5, the respondents perceived the development of work skills as very satisfactory with 4.11 as mean rating. The first item got the 
highest mean rating which indicates that they were able to develop effective and efficient ways of accomplishing a certain task. The fourth item got the lowest mean rating which states that the students observed proper care and maintenance of tools and equipment. The development of psychomotor skills through project making is considered as one of the expressive ways that provide the start of the development of basic skills in arts and crafts.

The activity enhances the students' opportunity to express themselves in constructing projects. They find project making very appealing for they like to manipulate, explore and create. The finding also implies that the development of work skills maximizes the students' potentials for self-fulfillment, develops effective and efficient ways of accomplishing tasks and enables them to observe proper care and maintenance of tools and equipment.

TABLE 6. Mean assessment of status of the technology, livelihood education program and development of work skills

\begin{tabular}{lccc}
\hline \multicolumn{1}{c}{$\begin{array}{c}\text { Status of the Technology and Livelihood } \\
\text { Education Program }\end{array}$} & \multicolumn{2}{c}{ Students' Development of Work Skills } \\
\cline { 2 - 5 } & Pearson Correlation & $\boldsymbol{p}$-value & Decision \\
\hline a. Curriculum Content & $0.480^{* *}$ & 0.000 & Reject Ho \\
\hline b. Instructional Methods & $0.599^{* *}$ & 0.000 & Reject Ho \\
\hline c. Faculty Competence & $0.562^{* *}$ & 0.000 & Reject Ho \\
\hline d. Adequacy of Facilities & $0.467^{* *}$ & 0.000 & Reject Ho \\
\hline${ }_{*}^{* *}$ Correlation is significant at the $p<.01$ & & &
\end{tabular}

Table 6 shows the test for significant relationship between the assessment of respondents towards the status of the technology and livelihood education program and their development in terms of "work skills". The decision is to reject the null hypothesis if the computed $\mathrm{p}$ - value is less than or equal to the 0.05 level of significance. Otherwise, do not reject the null hypothesis if the computed $\mathrm{p}$ - value is greater than the 0.05 level of significance. With $\mathrm{p}$ - values less than the 0.05 level of significance $(0.000,0.000,0.000$ and 0.000$)$, the researcher rejects the null hypothesis. Therefore, at $5 \%$ level of significance, there exists a significant relationship between the assessment of respondents towards the status of the technology and livelihood education program in terms of "Curriculum Content", "Instructional Methods", "Faculty Competence" and "Adequacy of Facilities".

\section{CONCLUSION}

The following conclusions are drawn:

1.The researchers concluded that the students perceived curriculum content and instructional methods as very good, faculty competence as very satisfactory, and adequacy of facilities as very adequate.

2. The development of the students in terms of work skills is very satisfactory. 3. The study revealed that the Status of Technology and Livelihood Education Program has a positively strong relationship with the Development of Work Skills.

In the light of the conclusions presented, the following recommendations are set forth.

1. Since the significant role of TLE school factors such as curriculum content, instructional methods, faculty competence and adequacy of facilities to the 
development of the students' work skills was confirmed in the study, the school administration must undertake the following:

- Provide more up-to-date instructional facilities for TLE;

- Assure full utilization of the instructional facilities;

- Settle the idea that facilities provide an environment that is safe, secured, comfortable, accessible, well-ventilated, well-illuminated, aesthetically pleasing, and should be an integral component of the conditions of learning;

- Undertake periodic review, evaluation and enrichment of curriculum content to strengthen life-long learning skills and work attitudes of students;

- Make improvement in the curriculum in such a way that the students can have a better chance to find out what their interests are;

- Find ways to increase funds for the improvement of the schools' facilities such as buildings, equipment and tools, and learning resources;

- Provide incentives and scholarships to teachers and facilitators in the form of seminars and the like to provide them the skills they need to succeed in a rapidly changing environment;

2. Teachers should have a wide variety of instructional methods, strategies, and approaches that they used during teaching-learning process.

3. Assessments on the teaching performance of teachers must be done on a regular basis because these will ensure quality output for both teachers and students.

\section{LIMITATIONS AND RECOMMEDNTIONS}

As this study took place in a single institute of Philippines hence, we can say that this study is limited in scope. The sample was not a true representative of whole population. This affects the generalizability of the findings. More research must be done in different regions and higher education institutes in future.

\section{REFERENCES}

Aquino. 2000. Instructional proficiency of the home technology teachers in cluster IV, division of Pampanga. Unpublished Master's Thesis, Don Honorio Ventura College of Arts and Trades, Bacoor, Pampanga.

Calmorin, Laurentina P. 1994. Educational research, measurement, and evaluation. Quezon: Philippine. Rex Book Store Inc.

Damian. 2012. Evaluation on the effectiveness of the polytechnic university of the Philippines business teacher education faculty. Unpublished undergraduate thesis, Polytechnic University of the Philippines, Manila, Philippines.

De Alca, Jocelyn D. A. 2008. Factors related to the performance of secondary students in technology and livelihood education at La Navas National High School. Unpublished Graduate thesis, Colegio de San Juan de Letran College, Manila, Philippines.

Holt. 2007. The nature of learner and teacher and how it affects curriculum and business. URL: https://sg.yahoo.com/?p=us (accessed on December 20, 2013).

Lackney and Picus. (2008) Impact of school facilities in the learning environment. URL: http://goo.gl/sKjdSR (accessed on February 4, 2014).

Ordonia. 2002. Development of instructional models in technology and livelihood education in Las Pinas NHSCAA Annex SY 2001-2002. Unpublished graduate thesis TUP, Manila, Philippines.

Sizoo, Steve L, Agrusa, Jerrome F, and Iskat Wilfried. 2005. Measuring and develop the learning strategies of adult career and vocational education students.

Weimer. 2008. Effective teaching strategies: The importance of marrying content and process. http://goo.gl/u3Cuoi (accessed on February 10, 2014).

— This article does not have any appendix. - 